\title{
ANALISIS EFEKTIVITAS DAN KONTRIBUSI PAJAK PENERANGAN JALAN TERHADAP PAJAK DAERAH DI KABUPATEN KEPULAUAN TALAUD
}

\author{
Lonex Dandel Anumpitan ${ }^{1}$ \\ Jantje J. Tinangon ${ }^{2}$ \\ Treesje Runtu ${ }^{3}$ \\ Fakultas Ekonomi dan Bisnis, Jurusan Akuntansi \\ Universitas Sam Ratulangi Manado \\ email: lanumpitan@gmail.com
}

\begin{abstract}
The construction of Talaud Regency encourages the occurrence of increased population, sights, hotels, restaurants and other entertainment venues. Improvement on some of the sectors with increasing power consumption in the Talaud Regency, which would then affect rapidly on increasing tax revenue potential of street lighting. The purpose of this research is to know the tax receipt street lighting in the Department of Revenue, Financial Management and Regional Assets Talaud regency. The results showed that the effectiveness of the tax revenue in the Talaud Regency street lighting from 2011-2015 average of 102.67\% - with a good category. While the tax contribution of street lighting towards acceptance of tax areas in the Talaud Regency in 2011-2015 average of 61.22\% by category is good enough. This means that the effectiveness of the tax revenue in the Talaud Regency street lighting has been very good and effective tax and contribution to street lighting towards the acceptance of tax areas in the Regency Talaud Regency are already good enough.
\end{abstract}

\section{Keywords : Street Lighting Tax, Effectiveness, Contributions}

\section{PENDAHULUAN}

\section{Latar Belakang}

Pembangunan ekonomi daerah khususnya kabupaten/ kota merupakan titik awal pelaksanaan pembangunan, sehingga daerah diharapkan bisa lebih mengetahui potensi dan apa yang menjadi kebutuhan daerahnya. Ugwuogo (2013) said construction also seen as a change of purpose in society that contributes to social and economic progress walfare good and it's people without any created lack of harmony within. Menurut Undang-Undang Nomor 12 Tahun 2008 tentang Pemerintah Daerah menyebutkan bahwa melalui otonomi daerah, pembangunan ekonomi daerah diharapkan terwujud melalui pengelolaan sumber-sumber daerah. The quality of governance, defined as a set of institutional arrangements that determine a sound environment for social and economic interaction, is an important factor of economic success (David Bartolini \& Raffaella Santolini, 2012).

Penerapan desentralisasi sebagai wujud dari otonomi daerah juga menimbulkan permasalahan dalam pembagian keuangan antara pusat dan daerah dimana pelaksanaan tugas dan wewenang masing-masing tingkat pemerintahan memerlukan dukungan pendanaan. Pemerintah daerah dalam hal ini dituntut memiliki kemandirian secara fiskal karena subsidi atau bantuan dari pemerintah pusat yang selama ini sebagai sumber utama dalam APBD, mulai kurang kontribusinya dan menjadi sumber utamanya adalah pendapatan dari daerah sendiri (Gomies \& Pattiasina, 2011).

Perkembangan pembangunan Kabupaten Kepulauan Talaud mendorong terjadinya peningkatan penduduk, objek wisata, hotel, restoran dan tempat hiburan lainnya. Peningkatan pada beberapa sektor tersebut seiring dengan meningkatnya pemakaian listrik di Kabupaten Kepulauan Talaud, yang kemudian akan berdampak pesat pada peningkatan potensi pajak penerangan jalan. Salah satu Pendapatan Asli Daerah di Kabupaten Kepulauan Talaud berasal dari pajak daerah, 
khususnya pajak penerangan jalan. Untuk itu Pemerintah Daerah Kabupaten Kepulauan Talaud telah mampu merealisasikan potensi pajak penerangan jalan tersebut sebesar mungkin, sehingga hal tersebut akan berdampak pada kenaikan realisasi Pendapatan Asli Daerah Kabupaten Kepulauan Talaud (Dinas Pendapatan, Pengelolaan Keuangan dan Aset Daerah Kabupaten Kepulauan Talaud, 2016).

\section{Tujuan Penelitian}

Tujuan penelitian ini adalah untuk Mengetahui efektivitas penerimaan dan kontribusi pajak penerangan jalan terhadap penerimaan pajak daerah di Kabupaten Kepulauan Talaud.

\section{TINJAUAN PUSTAKA}

\section{Pengertian Pajak}

Pajak adalah iuran masyarakat kepada kas negara berdasarkan undang-undang sehingga dapat dipaksakan dengan tidak mendapatkan balas jasa secara langsung. Pajak dipungut oleh pemerintah berdasarkan norma-norma hukum yang ada untuk menutup biaya produksi barang-barang dan jasa kolektif untuk dapat mencapai kesejahteraan umum (Widyaningsih, 2011).

\section{Fungsi Pajak}

Fungsi pajak menurut Widyaningsih (2011) adalah sebagai berikut.

1. Fungsi Penerimaan Budgeter yaitu pajak berfungsi sebagai sumber dana yang diperuntukkan bagi pembiayaan pengeluaran-pengeluaran pemerintahan. Dalam APBN, pajak merupakan sumber penerimaan dalam negeri

2. Fungsi Mengatur (Regulerend) yaitu Pajak berfungsi sebagai alat untuk mengatur atau melaksanakan kebijakan dibidang sosial dan ekonomi. Misalnya PPnBM untuk barang-barang mewah, hal ini diterapkan pemerintah dalam upaya mengatur agar tingkat konsumsi barangbarang mewah dapat dikendalikan.

3. Fungsi Stabilitas Fungsi ini berhubungan dengan kebijakan untuk menjaga stabilitas harga (melalui dana yang diperoleh dari pajak) sehingga laju inflasi dapat dikendalikan.

4. Fungsi RedistribusiDalam fungsi redistribusi, lebih ditekankan unsur pemerataan dan keadilan dalam masyarakat. Fungsi ini terlihat dari adanya lapisan tarif dalam pengenaan pajak.

5. Fungsi Demokrasi Pajak dalam fungsi demokrasi merupakan wujud sistem gotong royong. Fungsi ini dikaitkan dengan tingkat pelayanan pemerintah kepada masyarakat pembayar pajak.

\section{Tata Cara Pemungutan Pajak}

Menurut Mardiasmo (2011) ada 3 sistem pemungutan pajak,yakni:

1. Official assessment system

Adalah suatu sistem pemungutan yang member wewenang kepada pemerintah (Fiskus) untuk menentukan besarnya pajak yang terutang oleh wajib pajak. Ciri-cirinya :

a. Wewenang untuk menentukan besarnya pajak terutang ada pada fiskus.

b. Wajib pajak bersifat pasif.

c. Utang pajak timbul setelah setelah dikeluarkan surat ketetapan pajak oleh fiskus.

2. Self Assessment System

Adalah suatu sistem pemungutan pajak yang memberi wewenang kepada wajib pajak untuk menentukan sendiri besarnya pajak terutang.

Ciri-cirinya :

1. Wewenang untuk menentukan besarnya pajak terutang ada pada wajib pajak untuk menentukan sendiri,

2. Wajib pajak aktif, mulai dari menghitung, menyetor dan melaporkan sendiri pajak yang terutang,

3. Fiskus tidak ikut campur dan hanya mengawasi.

\section{With Holding System}

Adalah suatu sistem pemungutan pajak yang memberi wewenang kepada pihak ketiga (bukan fiskus dan bukan wajib pajak yang bersangkutan) untuk menentukan besarnya pajak yang terutang 
oleh wajib pajak. Ciri-cirnya: wewenang menentukan besarnya pajak yang terutang ada pada pihak ketiga, pihak selain fiskus dan wajib pajak.

\section{Jenis Pajak}

Secara umum, pajak yang berlaku di Indonesia dibedakan menjadi Pajak Pusat dan Pajak Daerah. Pajak pusat adalah pajak yang dikelolah oleh pemerintah pusat yang dalam hal ini sebagian dikelolah oleh Direktorat Jenderal Pajak - Departemen Keuangan. Sedangkan pajak daerah adalah pajak-pajak yang dikelolah oleh Pemeritah daerah baik ditingkat Provinsi maupun tingkat kabupaten/Kota.

Pajak pusat yang dikelolah oleh Direktorat Jenderal Pajak - Departemen Keuangan, meliputi: 1. Pajak Penghasilan (PPh)

PPh adalah pajak yang dikenakan kepada orang pribadi atau badan atas penghasilan yang diterima atau diperoleh dalam suatu tahun pajak. Yang dimaksud dengan penghasilan adalah setiap tambahan kemampuan ekonomis yang berasal baik dari Indonesia maupun luar Indonesia yang dapat digunakan untuk konsumsi atau untuk menambah kekayaan dengan nama dan dengan bentuk apapun. Dengan demikian maka penghasilan itu dapat berupa keuntungan usaha, gaji, hadiah, honorarium dan lain sebagainya.

2. Pajak Pertambahan Nilai (PPN)

PPN adalah pajak yang dikenakan atas konsumsi barang kena pajak atau jasa kena pajak di dalam daerah pabean. Orang pribadi, perusahaan maupun pemerintah yang mengkonsumsi barang kena pajak atau jasa kena pajak dikenakan PPN. Pada dasarnya setiap barang dan jasa adalah barang kena pajak atau jasa kena pajak, kecuali ditentukan lain oleh Undang-undang PPN. Tarif PPN adalah tunggal yaitu sebesar 10\%, dalam hal ekspor tarif PPN adalah 0\%. Yang dimaksud dengan wilayah pabean adalah wilayah republik Indonesia yang meliputi wilayah darat, perairan, dan ruang udara diatasnya.

3. Pajak Penjualan Atas Barang Mewah (PPn BM)

Selain dikenakan PPN, atas barang-barang kena pajak tertentu yang tergolong mewah, juga dikenakan PPn BM. Yang dimaksud dengan barang kena pajak yang tergolong mewah adalah:

a. Barang tersebut bukan merupakan barang kebutuhan pokok

b. Barang tersebut dikonsumsi oleh masyarakat tertentu

c. Pada umumnya barang tersebut dikonsumsi oleh masyarakat yang berpenghasilan tinggi.

d. Barang tersebut dikonsumsi untuk menunjukkan status

e. Apabila dikonsumsi dapat merusak kesehatan dan moral masyarakat serta mengganggu ketertiban masyarakat.

f. Bea Materai

Bea Materai adalah pajak yang dikenakan atas dokumen, seperti surat perjanjian, akta notaris, serta kuitansi pembayaran, surat berharga dan efek yang memuat jumlah uang atau nominal diatas jumlah tertentu sesuai dengan ketentuan.

4. Pajak Bumi dan Bangunan (PBB)

PBB adalah pajak yang dikenakan atas kepemilikan atau pemanfaatan tanah atau bangunan. PBB merupakan pajak pusat namun demikian hampir seluruh realisasi penerimaan PBB diserahkan kepada Pemerintah Daerah baik Provinsi maupun Kabupaten/Kota.

Pajak yang dipungut oleh Pemerintah Daerah baik Provinsi maupun Kabupaten/Kota antara lain meliputi:

1. Pajak Provinsi

a. Pajak kendaraan bermotor

b. Bea balik nama kendaraan bermotor

c. Pajak bahan bakar kendaraan bermotor

d. Pajak air permukaan

e. Pajak rokok

2. Pajak Kabupaten/Kota
a. Pajak hotel
b. Pajak restoran
c. Pajak hiburan 
d. Pajak reklame

e. Pajak penerangan jalan

f. Pajak mineral bukan logam dan batuan

g. Pajak parkir

h. Pajak air tanah

i. Pajak sarang burung walet

j. Pajak bumi dan bangunan pedesaan dan perkotaan

k. Bea perolehan hak atas tanah dan bangunan (BPHTB)

\section{Pengertian Pajak Daerah}

Sesuai dengan Undang-undang nomor 28 tahun 2009 tentang tentang Pajak Daerah dan Retribusi Daerah, yang dimaksud dengan pajak daerah yang selanjutnya disebut pajak, adalah iuran wajib yang dilakukan oleh orang pribadi atau badan kepada daerah tanpa imbalan langsung yang seimbang, yang dapat dipaksakan berdasarkan peraturan perundang-undangan yang berlaku, yang digunakan untuk membiayai penyelenggaraan pemerintah daerah dan pembanguan daerah.

\section{Tolok Ukur Penilaian Potensi Pajak Daerah}

Terdapat empat kriteria untuk menilai potensi pajak daerah yaitu:

1. Kecukupan dan elastisitas

Kecukupan dan elastisitas adalah kemampuan untuk menghasilkan tambahan pendapatan agar dapat menutup tuntutan yang sama atas kenaikan pengeluaran pemerintah dan dasar pengenaan pajaknya berkembang secara otomatis. Contoh : karena terjadi inflasi maka akan terjadi kenaikan harga-harga juga ada peningkatan jumlah penduduk dan bertambahnya pendapatan suatu daerah. Dalam hal ini elastisitas mempunyai dua dimensi yaitu:

a. Pertumbuhan potensi dari dasar pengenaan pajak itu sendiri

b. Sebagai kemudahan untuk memungut pertumbuhan pajak tersebut

Elastisitas dapat diukur dengan membandingkan hasil penerimaan selama beberapa tahun dengan perubahan-perubahan dalam indeks harga, penduduk maupun pendapatan nasional per kapita (GNP).

\section{Keadilan}

Prinsip keadilan yang dimaksud disini adalah bahwa pengeluaran pemerintah haruslah dipikul oleh semua golongan masyarakat sesuai dengan kekayaan dan kesanggupan masing-masing golongan.

3. Kemampuan administrasi

Kemampuan administrasi yang dimaksud disini mengandung pengertian bahwa waktu yang diberikan dan biaya yang dikeluarkan dalam menetapkan dan memungut pajak sebanding dengan hasil yang mampu dicapai.

4. Kesepakatan politis

Kesepakatan politis diperlukan dalam pengenaan pajak, penetapan struktur tarif, memutuskan siapa yang harus membayar dan bagaimana pajak tersebut ditetapkan dan memberikan sanksi bagi yang melanggarnya.

\section{Pengertian Pajak Penerangan Jalan}

Menurut Keputusan Menteri Dalam Negeri Nomor 10 tahun 2002 pajak penerangan jalan adalah pajak atas penggunaan tenaga listrik dengan ketentuan bahwa di wilayah daerah tersebut tersedia penerangan jalan, yang rekeningnya dibayar oleh Pemerintah Daerah

\section{Perhitungan Pajak Penerangan Jalan}

Pajak penerangan jalan dapat dihitung dengan cara mengalikan tarif pajak dengan dasar pengenaan pajak. Atau bila dituliskan dalam bentuk rumus sebagai berikut:

Pajak terutang $=$ Tarif pajak $\mathrm{x}$ Dasar pengenaan pajak

$$
\text { =Tarif pajak x Nilai Jual Tenaga Listrik }
$$




\section{Pemungutan Pajak Penerangan Jalan}

Sistem pemungutan pajak penerangan jalan ada dua macam, yaitu:

1. Tenaga listrik yang disediakan PLN

2. Tenaga listrik yang disediakan oleh Bukan PLN

\section{Objek Pajak Penerangan Jalan}

Dalam Perda Kabupaten Talaud No. 3 Tahun 2011 tentang Pajak Daerah dan Retribusi Daerah, objek pajak penernagan jalan adalah penggunaan tenaga listirik baik yang dihasilkan sendiri maupun yang diperoleh dari sumber lain.

\section{Efektivitas Pajak Penerangan Jalan}

Indrakusuma (2011) menyatakan efektivitas adalah ukuran antara hasil output dengan hasil pungut suatu pajak dengan potensi pajak itu sendiri. Efektivitas juga berhubungan dengan derajat keberhasilan suatu operasi pada sektor publik sehingga suatu kegiatan dikatakan efektif jika kegiatan tersebut mempunyai pengaruh besar terhadap kemampuan menyediakan pelayanan masyarakat yang merupakan sasaran yang telah ditentukan.

\section{Kontribusi Pajak Penerangan Jalan}

Kontribusi digunakan untuk mengetahui sejumlah mana pajak penerangan jalan memberikan sumbangan dalam penerimaan pajak daerah. Semakin besar hasilnya berarti semakin besar pula peranan pajak penerangan jalan terhadap pajak daerah, begitu pula sebaliknya jika hasil perbandingannya terlalu kecil berarti peranan pajak penerangan jalan terhadap pajak daerah juga kecil (Mahmudi, 2010).

\section{METODE PENELITIAN}

\section{Jenis Penelitian}

Jenis penelitian yang digunakan adalah metode deskriptif. Dengan menggunakan metode penelitian diketahui hubungan yang signifikan antara variabel yang diteliti sehingga menghasilkan kesimpulan yang akan memperjelas gambaran mengenai objek yang diteliti. Pengertian metode deskriptif menurut Sugiyono (2012:29) adalah sebagai berikut: "Metode deskriptif adalah metode yang digunakan untuk menggambarkan atau menganalisis suatu hasil penelitian tetapi tidak digunakan untuk membuat kesimpulan yang lebih luas".

\section{Tempat dan Waktu Penelitian}

Penelitian ini dilakukan di Dinas Pendapatan, Pengelolaan Keuangan dan Aset Daerah (DPPKAD) Kabupaten Kepulauan Talaud. Periode waktu penelitian dimulai dari bulan April sampai dengan Mei 2016.

\section{Metode Pengumpulan Data}

Jenis data yang digunakan pada penelitian ini yaitu melalui studi kepustakaan serta penelitian lapangan dengan cara dokumentasi, observasi serta wawancara.

\section{Metode Analisis}

Metode analisis yang digunakan dalam penelitian ini adalah analisis deskriptif. Metode deskriptif yaitu suatu metode pembahasan masalah yang sifatnya menguraikan, menggambarkan, membandingkan suatu data atau keadaan serta melukiskan dan menerangkan suatu keadaan sedemikian rupa sehingga dapatlah ditarik suatu kesimpulan.. Adapun langkah-langkah pengolahan data adalah sebagai berikut.

1. Pengukuran Efektivitas Pajak Penerangan Jalan

Menurut Indrakusuma (2011), rumus penghitungan efektivitas pajak penerangan jalan yang digunakan adalah sebagai berikut:

$$
\text { Efektivitas Pajak Penerangan Jalan }=\frac{\text { Realisasi Pajak Penerangan Jalan }}{\text { Target Pajak Penerangan Jalan }} \times 100 \%
$$


Dari rumus perhitungan efektivitas tersebut, dapat disusun kriteria efektivitasnya. Indrakusuma (2011) mengungkapkan efektivitas digolongkan sebagai berikut:

Tabel 1. Klasifikasi Kriteria Efektivitas

\begin{tabular}{cc} 
Ukuran & Kategori \\
\hline $0-33,33 \%$ & Buruk \\
$33,33 \%-66,66 \%$ & Cukup efektif \\
$>66,66 \%$ & Baik \\
\hline
\end{tabular}

Sumber : Indrakusuma, 2011

2. Pengukuran Kontribusi Pajak Penerangan Jalan Terhadap Penerimaan Pajak Daerah Dalam penelitian ini rumus penghitungan kontribusi pajak penerangan jalan terhadap penerimaan pajak yang digunakan adalah sebagai berikut:

Kontribusi Pajak Penerangan Jalan $=\frac{\text { Realisasi Pajak Penerangan Jalan }}{\text { Total Penerimaan Pajak Daerah }} \times 100 \%$

Besarnya kontribusi menurut Serdana (2013) digolongkan ke dalam kategori sebagai berikut:

Tabel 2. Klasifikasi Kriteria Kontribusi

\begin{tabular}{cc}
\hline Ukuran & Kategori \\
\hline $0 \%-19 \%$ & Kurang Sekali \\
$20 \%-39 \%$ & Besar \\
$40 \%-59 \%$ & Cukup Besar \\
$60 \%-79 \%$ & Cukup Baik \\
$80 \%-100 \%$ & Besar Sekali \\
\hline
\end{tabular}

Sumber : Serdana, 2013

\section{HASIL PENELITIAN DAN PEMBAHASAN}

\section{Gambaran Umum Objek Penelitian}

Secara Geografis kepulauan Talaud terletak diantara Pulau Mindanao (Filipina) dan Pulau Sulawesi. Kepulauan Talaud adalah gugusan pulau-pulau yang berada di utara Indonesia dengan batas-batas wilayah sebagai berikut:

1. Sebelah Utara berbatasan dengan Negara Filipina

2. Sebelah Selatan berbatasan dengan laut Maluku

3. Sebelah Barat berbatasan dengan laut Sulawesi

4. Sebelah Timur berbatasan dengan Samudera Pasifik

Kepulauan Talaud terdiri dari 20 pulau yaitu pulau Karakelang (terbesar), Mangaran, Salibabu, Miangas, Marampit, Karatung, Kakorotan dan pulau - pulau tidak berpenghuni lainnya. Kabupaten Kepulauan Talaud terbentuk berdasarkan Undang-Undang No. 8 Tahun 2002 yang merupakan hasil pemekaran Kabupaten Sangihe dan Talaud dengan Ibu Kota Melonguane. Luas wilayah Kabupaten Talaud secara keseluruhan adalah $27.061,16 \mathrm{~km} 2$ yang terdiri dari daratan seluas $1.288,94 \mathrm{~km} 2$ dan lautan seluas 25.772,22 km2 dengan jumlah Penduduk 91.067 jiwa.

\section{Visi dan Misi Kabupaten Kepulauan Talaud}

Dalam tahun periode 2015-2019, Visi Pembangunan Kabupaten Kepulauan Talaud, yang merupakan visi Bupati dan Wakil Bupati terpilih adalah: "Mewujudkan Masyarakat Kepulauan Talaud Yang Rukun Dan Damai, Bebas Dari Kolusi, Korupsi Dan Nepotisme". Untuk mewujudkan Visi tersebut, maka Misi Daerah Kabupaten Kepulauan Talaud adalah : 
1. Membangun Pemerintahan yang Bersih dan Berwibawa yang Berorientasi pada Layanan Masyarakat.

2. Meningkatkan Manajemen Pemerintahan yang Berdaya Guna dan Berorientasi pada Keahlian, Profesional "The Right Man On The Right Place".

3. Mengembangkan Manajemen Pendidikan yang Berkualitas dengan Berorientasi pada Peningkatan Sumber Daya Manusia.

4. Membangun Sistem Pelayanan Kesehatan yang Murah, Cepat, Ramah dan Manusiawi.

5. Membangun Percepatan dan Peningkatan Infrastruktur.

6. Meningkatkan Peran Agama, Adat, Budaya dalam rangka Menciptakan Masyarakat Talaud yang Rukun dan Damai.

\section{Visi dan Misi Dinas Pendapatan Pengelolaan Keuangan dan Aset Daerah}

Visi DPPKAD dirumuskan dengan memperhatikan visi dan misi Kepala Daerah yang ditetapkan dalam Rencana Pembangunan Jangka Menengah Daerah (RPJMD) Kabupaten Kepulauan Talaud Tahun 2015 - 2019, dengan visi : "Mewujudkan Masyarakat Kepulauan Talaud yang Rukun dan Damai, bebas dari Kolusi, Korupsi dan Nepotisme". Sedangkan misi yang diemban oleh DPPKAD Kabupaten Kepulauan Talaud adalah misi 2, yakni: Meningkatkan Manajemen Pemerintahan Yang Berdaya Guna Dan Berorientasi Pada Keahlian, Profesionalisme "The Right Man on The Right Place". Berdasarkan pada visi dan misi Kepala Daerah dan Wakil Kepala Daerah, visi DPPKAD ditetapkan sebagai berikut : "Terwujudnya Pengelolaan Pendapatan, Keuangan, Dan Aset Daerah Yang Berkualitas, Transparan, Partisipatif, Dan Akuntabel Yang Di Dukung Oleh Aparatur Yang Profesional ". Misi Dinas Pendapatan, Pengelolaan Keuangan dan Aset Daerah Kabupaten Kepulauan Talaud merupakan pernyataan mengenai garis besar kiprah utama Dinas Pendapatan, Pengelolaan Keuangan dan Aset Daerah Kabupaten Kepulauan Talaud dalam mewujudkan visi di atas. Maka Dinas Pendapatan, Pengelolaan Keuangan dan Aset Daerah Kabupaten Kepulauan Talaud menetapkan misi, sebagai berikut :

1. Meningkatkan kualitas dan profesionalisme sumber daya manusia (SDM) aparatur pengelolaan pendapatan, pengelolaan keuangan dan aset;

2. Meningkatkan pendapatan daerah;

3. Meningkatkan Kualitas sistem pengelolaan keuangan dan aset daerah sesuai dengan peraturan yang berlaku;

\section{Tugas Pokok}

Dinas Pendapatan Pengelolaan Keuangan dan Aset Daerah mempunyai tugas membantu Bupati dalam penyelenggaraan urusan pemerintahan daerah sebagai perangkat daerah otonom di bidang Pendapatan, Pengelolaan Keuangan dan Aset Daerah.

\section{Fungsi}

Dalam menyelenggarakan tugas sebagainama tersebut pada point 4.1.5 Dinas Pendapatan, Pengelolaan Keuangan dan Aset Daerah mempunyai fungsi:

a. Menyelenggarakan urusan pemerintahan dan pelayanan umum di bidang Pendapatan, Pengelolaan Keuangan dan Aset Daerah.

b. Merencanakan dan merumuskan kebijakan teknis di bidang Pendapatan, Pengelolaan Keuangan dan Aset Daerah.

c. Melaksanakan pembinaan serta pengembangan sumber-sumber pendapatan daerah.

d. Melaksanakan pengawasan dan pengendalian anggaran di bidang Pendapatan, Pengelolaan Keuangan dan Aset Daerah.

e. Pelaksanaaan Tugas Kesekretariatan dan tugas lainnya yang diberikan oleh Bupati.

\section{Susunan Organisasi}

Susunan organisasi Dinas Pendapatan, Pengelolaan Keuangan dan Aset Daerah berdasarkan Peraturan Daerah Nomor 05 Tahun 2008 tentang Organisasi dan Tata Kerja Dinas-Dinas Daerah Kabupaten Kepulauan Talaud terdiri dari :

1. Kepala Dinas; 
2. Sekretariat;

3. Bidang;

4. Sub Bagian;

5. Seksi;

6. Kelompok Jabatan Fungsional;

1. Sekretaris membawahi 3 (tiga) sub bagian, yaitu:

a. Sub Bagian Perencanaan, Evaluasi dan Pelaporan

b. Sub Bagian Umum dan Kepegawaian

c. Sub Bagian Keuangan

2. Bidang - bidang terdiri dari :

a. Bidang Pendapatan dan Penetapan

b. Bidang Penagihan dan Penerimaan

c. Bidang Anggaran

d. Bidang Akuntansi

e. Bidang Aset dan Investasi

a. Bidang Pendataan dan Penetapan membawahi 3 (tiga) seksi yaitu:

1. Seksi Pendataan dan Bagi Hasil

2. Seksi Pendaftaran

3. Seksi Penetapan

b. Bidang Penagihan dan Penerimaan membawahi 3 (tiga) seksi, yaitu:

1. Seksi Perhitungan

2. Seksi Pertimbangan dan Keberatan

3. Seksi Penagihan, Penatausahaan dan Pelaporan

c. Bidang Anggaran membawahi 3 (tiga) seksi, yaitu:

1. Seksi Penyusunan Anggaran Belanja Langsung

2. Seksi Penyusunan Anggaran Belanja Tidak Langsung

3. Seksi Bina Administrasi Anggaran Desa

d. Bidang Akuntansi 3 (tiga) seksi, yaitu:

1. Seksi Verifikasi dan Penatausahaan Keuangan Daerah

2. Seksi Akuntansi dan Pengelolaan Gaji

3. Seksi Penyusunan Laporan Keuangan Daerah

e. Bidang Pengelolaan Aset dan Investasi Daerah membawahi 3 (tiga) seksi, yaitu:

1. Seksi Perencanaan dan Pengadaan Aset

2. Seksi Akuisisi, Pengamanan, Pemeliharaan dan Penghapusan Aset

3. Seksi Pemanfaatan Aset dan Pengelolaan Investasi Daerah

\section{Hasil Penelitian}

Dalam penelitian ini akan ditinjau tentang penerimaan salah satu pajak daerah yaitu pajak penerangan jalan. Penerimaan pajak penerangan jalan di Kabupaten Kepulauan Talaud menemui beberapa masalah/kendala sehingga beberapa tahun terakhir tidak mencapai target yang ditetapkan per tahunnya. Pajak penerangan jalan merupakan salah satu pajak daerah kabupaten/kota. Keputusan Menteri Dalam Negeri No.10 tahun 2002 pajak penerangan jalan adalah pajak atas penggunaan tenaga listrik dengan ketentuan bahwa di wilayah daerah tersebut tersedia penerangan jalan, yang rekeningnya dibayar oleh Pemerintah Daerah. Sehingga penerimaan pajak yang diperoleh dari pajak penerangan jalan akan digunakan untuk membiayai penerangan jalan pada jalan umum meliputi pemeliharaan dan perbaikan lampu jalan.

Penerimaan pajak penerangan jalan dalam penelitian ini digunakan sebagai informasi yang menunjukkan upaya pemerintah Kabupaten Kepulauan Talaud dalam hal ini pihak Dinas Pendapatan, Pengelolaan Keuangan dan Aset Daerah (DPPKAD) Kabupaten Kepulauan Talaud untuk selalu mengoptimalisasi segala potensi yang ada di Kabupaten Kepulauan Talaud, di samping itu data pajak penerangan jalan bagi daerah merupakan info yang berguna untuk merencanakan pembangunan pada masa-masa mendatang. 
Tabel 3. Target Penerimaan Pajak Penerangan Kabupaten Kepulauan Talaud Tahun 2011 - 2015

\begin{tabular}{cccc}
\hline No & Tahun & $\begin{array}{c}\text { Target } \\
\text { Pajak Penerangan Jalan }(\mathbf{R p})\end{array}$ & $\begin{array}{c}\text { Pertumbuhan } \\
(\boldsymbol{\%})\end{array}$ \\
\hline 1 & 2011 & 895.590 .378 & - \\
2 & 2012 & 1.035 .355 .547 & 15,60 \\
3 & 2013 & 1.153 .837 .975 & 11,44 \\
4 & 2014 & 1.067 .662 .973 & $-9,25$ \\
5 & 2015 & 1.782 .524 .742 & 66,95 \\
\hline
\end{tabular}

Sumber: Dinas Pendapatan, Pengelolaan Keuangan dan Aset Daerah Kabupaten Kepulauan Talaud, 2016

Berdasarkan data diatas memperlihatkan bahwa target pajak penerangan jalan yang ditetapkan Pemerintah Kabupaten Kepulauan Talaud dalam hal ini pihak DPPKAD Kabupaten KepulauanTalaud selalu meningkat dari tahun ke tahun, kecuali pada tahun 2014 mengalami penurunan. Pada tahun 2011 target pajak penerangan jalan kabupaten Talaud sebesar Rp. 895.590.378 kemudian pada tahun 2012 meningkat sebesar 15,60\% menjadi Rp 1.035.355.547, tahun 2013 meningkat sebesar 11,44\% menjadi Rp. 1.153.837.975, tahun 2014 menurun sebesar 9,25\% menjadi Rp. 1.067.662.973 dan tahun 2015 meningkat sebesar 66,95\% menjadi Rp 1.782.524.742. Pada Tabel 4.2 akan memperlihatkan realisasi penerimaan pajak penerangan jalan Kabupaten Kepulauan Talaud Tahun 2011 sampai dengan tahun 2015.

Tabel 4. Realisasi Penerimaan Pajak Penerangan Kabupaten Kepulauan Talaud Tahun 2011 - 2015

\begin{tabular}{|c|c|c|c|}
\hline No & Tahun & $\begin{array}{c}\text { Realisasi } \\
\text { Penerimaan Pajak Penerangan Jalan (Rp) }\end{array}$ & $\begin{array}{c}\text { Pertumbuhan } \\
\%\end{array}$ \\
\hline 1 & 2011 & 938.586 .110 & - \\
\hline 2 & 2012 & 1.143 .875 .713 & 21,87 \\
\hline 3 & 2013 & 1.297 .682 .558 & 13,44 \\
\hline 4 & 2014 & $1.372 .231,353$ & 5,74 \\
\hline 5 & 2015 & 1.017 .322 .185 & $-74,13$ \\
\hline
\end{tabular}
Kepulauan Talaud, 2016

Berdasarkan data diatas memperlihatkan bahwa pada tahun 2011 realisasi pajak penerangan jalan Kabupaten Kepulauan Talaud sebesar Rp. 938.586.110, kemudian pada tahun 2012 meningkat sebesar 21,87\% menjadi Rp. 1.143.875.713, tahun 2013 meningkat sebesar 13,44\% menjadi Rp. 1.297.682.558, tahun 2014 kembali meningkat sebesar 5,74\% menjadi Rp. 1.372.231,353 dan tahun 2015 menurun sebesar 74,13\% menjadi Rp. 1.017.322.185. Pada Tabel 4.3 akan memperlihatkan Total penerimaan pajak daerah Kabupaten Kepulauan Talaud Tahun 2011 sampai dengan tahun 2015.

Tabel 5. Total Penerimaan Pajak Daerah Kabupaten Kepulauan Talaud Tahun 2011-2015

\begin{tabular}{cccc}
\hline No & Tahun & Total Penerimaan Pajak Daerah (Rp) & $\begin{array}{c}\text { Pertumbuhan } \\
\mathbf{\%}\end{array}$ \\
\hline 1 & 2011 & 1.194 .190 .378 & - \\
2 & 2012 & 1.353 .990 .000 & 13,38 \\
3 & 2013 & 1.714 .568 .537 & 26,63 \\
4 & 2014 & 3.260 .290 .017 & 90,15 \\
5 & 2015 & 4.026 .661 .992 & 23,50 \\
\hline \multicolumn{5}{c}{ Sumber: } & Dinas & Pendapatan, Pengelolaan Keuangan dan Aset Daerah Kabupaten
\end{tabular}

Kepulauan Talaud, 2016 
Berdasarkan data diatas menunjukkan bahwa pada tahun 2011 penerimaan pajak daerah di Kabupaten Kepulauan Talaud sebesar Rp. 1.194.190.378, kemudian pada tahun 2012 meningkat sebesar 13,38 \% menjadi Rp. 1.353.990.000, tahun 2013 meningkat sebesar 26,63 \% menjadi Rp. 1.714.568.537, tahun 2014 kembali meningkat sebesar 90,15\% menjadi Rp. 3.260.290.017 dan tahun 2015 meningkat lagi sebesar 23,50 \% menjadi Rp. 4.026.661.992.

\section{Pembahasan}

Tabel 6. Efektivitas Penerimaan Pajak Penerangan Jalan di Kabupaten Kepulauan Talaud Tahun 2011-2015

\begin{tabular}{ccccc}
\hline No & Tahun & $\begin{array}{c}\text { Target Pajak Penerangan } \\
\text { Jalan } \\
(\mathbf{R p})\end{array}$ & $\begin{array}{c}\text { Realisasi Pajak } \\
\text { Penerangan Jalan (Rp) }\end{array}$ & $\begin{array}{c}\text { Efektivitas } \\
\mathbf{\%}\end{array}$ \\
\hline 1 & 2011 & 895.590 .378 & & \\
2 & 2012 & 1.035 .355 .547 & 938.586 .110 & 104,80 \\
3 & 2013 & 1.153 .837 .975 & 1.143 .875 .713 & 110,48 \\
4 & 2014 & 1.067 .662 .973 & 1.297 .682 .558 & 112,46 \\
5 & 2015 & 1.782 .524 .742 & $1.372 .231,353$ & 128,52 \\
\hline
\end{tabular}

Sumber: Data Olahan Hasil Penelitian, 2016.

Berdasarkan data diatas diketahui bahwa efektivitas penerimaan pajak penerangan jalan Kabupaten Kepulauan Talaud dari tahun 2011 - 2015 mengalami fluktuatif. Pada tahun 2011 efektivitas penerimaan pajak penerangan jalan sebesar 104,80\% dan pada tahun 2012 meningkat menjadi 110,48 \%, tahun 2013 meningkat sebesar 112,46\%, tahun 2014 meningkat lagi sebesar $128,52 \%$, rata-rata tahun 2011 sampai dengan tahun 2014 mengalami peningkatan karena bertambahnya jumlah pelanggan. Sedangkan pada tahun 2015 efektivitas penerimaan pajak penerangan jalan Kabupaten Kepulauan Talaud menurun sebesar 57,07 \%, disebabkan oleh ketidakpatuhan beberapa pelanggan dalam membayar rekening listrik.

Tabel 7. Kontribusi Pajak Penerangan Jalan Terhadap Penerimaan Pajak Daerah di Kabupaten Kepulauan Talaud Tahun 2011-2015

\begin{tabular}{ccccc}
\hline No & Tahun & $\begin{array}{c}\text { Realisasi Pajak Penerangan } \\
\text { Jalan } \\
(\mathbf{R p})\end{array}$ & $\begin{array}{c}\text { Total Penerimaan Pajak } \\
\text { Daerah } \\
(\mathbf{R p})\end{array}$ & $\begin{array}{c}\text { Kontribusi } \\
\mathbf{\%}\end{array}$ \\
\hline 1 & 2011 & 938.586 .110 & 1.194 .190 .378 & 78,59 \\
2 & 2012 & 1.143 .875 .713 & 1.353 .990 .000 & 84,48 \\
3 & 2013 & 1.297 .682 .558 & 1.714 .568 .537 & 75,68 \\
4 & 2014 & $1.372 .231,353$ & 3.260 .290 .017 & 42,08 \\
5 & 2015 & 1.017 .322 .185 & 4.026 .661 .992 & 25,26 \\
\hline
\end{tabular}

Sumber: Data Olahan Hasil Penelitian, 2016.

Berdasarkan data diatas dapat diketahui bahwa kontribusi pajak penerangan jalan terhadap penerimaan pajak daerah di Kabupaten Kepulauan Talaud dari tahun 2011 sampai dengan 2015 mengalami fluktuatif. Pada tahun 2011 kontribusi penerimaan pajak penerangan jalan terhadap penerimaan pajak daerah sebesar 78,59 \% dan pada tahun 2012 meningkat menjadi 84,48 \%, sedangkan pada tahun 2013 sampai dengan tahun 2015 kontribusi pajak penerangan jalan terhadap penerimaan pajak daerah Kabupaten Kepulauan Talaud mengalami penurunan. Pada tahun 2013 turun sebesar 75,68 \%, tahun 2014 menurun sebesar 42,08 \%, dan pada tahun 2015 menurun lagi sebesar $25,26 \%$ 
Tabel 8. Tingkat Efektivitas Pajak Penerangan dan Kontribusinya Terhadap Penerimaan Pajak Daerah Kabupaten Kepulauan Talaud Tahun 2011 - 2015

\begin{tabular}{cccccc}
\hline No & Tahun & Efektivitas & Kategori & Kontribusi & Kategori \\
\hline 1 & 2011 & $104,80 \%$ & Baik & $78,59 \%$ & Cukup Baik \\
2 & 2012 & $110,48 \%$ & Baik & $84,48 \%$ & Besar Sekali \\
3 & 2013 & $112,46 \%$ & Baik & $75,68 \%$ & Cukup Baik \\
4 & 2014 & $128,52 \%$ & Baik & $42,08 \%$ & Cukup Besar \\
5 & 2015 & $57,07 \%$ & Cukup Efektif & $25,26 \%$ & Besar \\
\hline
\end{tabular}

Sumber: Data Olahan Hasil Penelitian, 2016.

Berdasarkan data diatas dapat disimpulkan bahwa efektivitas pajak penerangan jalan di Kabupaten Kepulauan Talaud dari tahun 2011 sampai dengan 2015 rata - rata sebesar 102,67 \% dengan kategori baik. Hal ini berarti bahwa penerimaan pajak penerangan jalan di Kabupaten Kepulauan Talaud sudah baik dan efektif. Untuk kedepannya Pemerintah Daerah harus bisa meningkatkan penerimaan pajak penerangan jalan sehingga efektivitas penerimaan pajak ini dapat lebih baik dan sangat efektif agar penerimaannya senantiasa dapat ditingkatkan dari tahun ke tahun.

Kontribusi pajak penerangan jalan terhadap penerimaan pajak daerah di Kabupaten Kepulauan Talaud tahun 2011 sampai dengan 2015 rata-rata sebesar 61,22 \% dengan kategori cukup baik. Hal ini berarti bahwa kontribusi pajak penerangan jalan terhadap penerimaan pajak daerah di Kabupaten Kepulauan Talaud sudah cukup baik. Jadi diharapkan Pemerintah Daerah dalam hal ini Dinas Pendapatan, Pengelolaan Keuangan dan Aset Daerah Kabupaten Kepulauan Talaud harus dapat meningkatkan lagi kontribusi pajak penerangan jalan terhadap penerimaan pajak daerah, agar supaya dapat meningkatkan Pendapatan Asli Daerah di Kabupaten Kepulauan Talaud.

\section{Kesimpulan}

\section{PENUTUP}

Penelitian ini dimaksudkan untuk menganalisis efektivitas pajak penerangan jalan dan kontribusi pajak penerangan jalan terhadap penerimaan pajak daerah di Kabupaten Kepulauan Talaud. Dari analisis data yang telah dilakukan dapat di ambil beberapa kesimpulan sebagai berikut:

1. Tingkat efektivitas penerimaan pajak penerangan jalan di Kabupaten Kepulauan Talaud dari tahun 2011 sampai dengan 2015 rata - rata sebesar 102,67 \% dengan kategori baik. Hal ini berarti bahwa penerimaan pajak penerangan jalan di Kabupaten Kepulauan Talaud sudah sangat baik dan efektif.

2. Kontribusi pajak penerangan jalan terhadap penerimaan pajak daerah di Kabupaten Kepulauan Talaud tahun 2011 sampai dengan 2015 rata-rata sebesar 61,22\% dengan kategori cukup baik. Hal ini berarti bahwa kontribusi pajak penerangan jalan terhadap penerimaan pajak daerah di Kabupaten Kepulauan Talaud sudah cukup baik.

\section{Saran}

Melihat efektivitas penerimaan pajak penerangan jalan dan kontribusi pajak penerangan terhadap penerimaan pajak daerah di Kabupaten Kepulauan Kabupaten Talaud mempunyai peluang keberhasilan cukup tinggi karena memiliki potensi penerimaan yang baik dan efektif. Untuk itu perlu usaha dari Pemerintah Daerah dan pihak-pihak terkait untuk meningkatkan keberhasilan pajak penerangan jalan di Kabupaten Kepulauan Talaud sehingga efektivitas penerimaan pajak penerangan jalan dan kontribusi pajak penerangan jalan terhadap pajak daerah dapat ditingkatkan lagi. Adapun beberapa saran yang dapat disampaikan antara lain sebagai berikut:

1. Pemerintah Daerah dalam hal Dinas Pendapatan, Pengelolaan Keuangan dan Aset Daerah (DPPKAD) Kabupaten Kepulauan Talaud harus melengkapi dan melakukan validasi data - data yang dimiliki oleh daerah, khususnya data - data tentang pajak penerangan jalan.

2. Dinas Pendapatan, Pengelolaan Keuangan dan Aset Daerah (DPPKAD) Kabupaten Kepulauan Talaud harus melakukan koordinasi dengan PT. PLN Persero dalam mengelola Pajak Penerangan Jalan, hal ini bertujuan agar DPPKAD Kabupaten Kepulauan Talaud dapat mengetahui seberapa besar potensi pajak penerangan jalan yang dimiliki, supaya tidak terjadi kesalahan dalam penetapan target. 


\section{DAFTAR PUSTAKA}

Bartolini, David and Raffaella Santolini. 2012. "Regional Autonomy and The Quality Of Governance In OECD Countries".

Dinas Pendapatan, Pengelolaan Keuangan dan Aset Daerah, 2016. Kerangka Acuan Kerja (KAK) Kegiatan Rapat Koordinasi Dan Evaluasi PAD/PBB Program Peningkatan Dan Pengembangan Pengelolaan Keuangan Daerah Tahun Anggaran 2016.

Gomes, Stevanus J. Dan Victor Pattiasina. 2011. Analisis Kontribusi Pajak Daerah dan Retribusi Daerah Terhadap Pendapatan Asli Daerah di Kabupaten Maluku Tenggara. Aset : Volume 13, Nomor 2, Halaman 175-183.

Indrakusuma, 2011. Potensi Penerimaan dan Efektifitas Pajak Penerangan Jalan di Kota Semarang. Jurnal. Universitas Diponegoro. http://eprints.binus.ac.id/23413/.. Diakses 9 Mei 2016.

Keputusan Menteri Dalam Negeri Nomor 10 tahun 2002 Tentang Pajak Penerangan Jalan.

Mardiasmo. 2011. Perpajakan, Edisi Revisi. ANDI. Yogyakarta.

Peraturan Daerah Kabupaten Kepulauan Talaud Nomor 3 Tahun 2011 Tentang Pajak Daerah.

Peraturan Daerah Nomor 05 Tahun 2008 tentang Organisasi dan Tata Kerja Dinas-Dinas Daerah Kabupaten Kepulauan Talaud.

Serdana, I Ketut Ari. dkk, 2013, "Efektivitas dan Kontribusi Pajak Hotel dan Pajak Restoran terhadap PAD Kabupaten Gianyar tahun 2010-2012”, Jurusan Pendidikan Ekonomi, Fakultas Ekonomi dan Bisnis, Universitas Pendidikan Ganesha, Singaraja Bali.

Sugiyono, 2012. Statistika Untuk Penelitian. Alfabeta. Bandung.

Ugwuogo, Christopher C. 2013. "Business Education and National Development: Issues and Challenges". Journal of Educational and Social Research. Vol. 3.

Undang-Undang Nomor 28 tahun 2009 tentang Pajak Daerah dan Retribusi Daerah.

Widyaningsih, Aristanti, 2011. Hukum Pajak Dan Perpajakan. Alfabeta. Bandung. 